\title{
LIFE CYCLE OF BIOMASS BLENDING IN ELECTRICITY GENERATION: AN ENVIRONMENTAL AND ECONOMIC ASSESSMENT
}

\author{
Shafini Mohd Shafie ${ }^{1 *}$, Zakirah Othman ${ }^{1}$, Norsiah Hami ${ }^{1}$ \\ ${ }^{1}$ School of Technology Management and Logistics, College of Business, Universiti Utara Malaysia, \\ 06000 Sintok, Kedah, Malaysia
}

(Received: July 2018 / Revised: September 2018 / Accepted: December 2018)

\begin{abstract}
Recently, biomass resources have faced issues with the security of resources supply. Biomass blending could provide the solution to overcome this limitation. This study aimed to determine the life cycle assessment of the biomass blending of paddy residue, cash crop, industrial crop, and garden waste in electricity generation. The analysis are related to environmental and cost assessments. The life cycle includes the process of crop production, crop collection, transportation, collection center, and power plant. The results obtained the range for greenhouse gas (GHG) emissions, varying from $0.02 \mathrm{~kg} \mathrm{CO} 2 \mathrm{EQ} / \mathrm{kWh}$ to $6400.04 \mathrm{~kg} \mathrm{CO} 2 \mathrm{EQ} / \mathrm{kWh}$, whereas the cost varied from RM0.01/kWh to RM16.10/kWh. The transportation process is the most critical process requiring extra extension, due to the high GHG emissions and consumption cost for that process. The output from this research is hoped to serve as the guideline for biomass utilization development in Malaysia.
\end{abstract}

Keywords: Biomass blending; Economics; Electricity generation; Environment; Life cycle assessment

\section{INTRODUCTION}

Biomass is seen as one of the key options in the mitigation of greenhouse gas (GHG) emissions and the substitution of conventional electrical generation methods. Due to the current climate change issue, many researchers are recommending the reuse of waste and the reduction of environmental pollution (Zakareta \& Shafie, 2016; Hossain et al., 2017). These recommendations are also due to the resources security of the conventional fuel supply. At present, biomass resources comprise about $10 \%$ of global energy sources, where half of biomass energy generated are used in developing countries for domestic consumption. The countries that fully utilize biomass energy sources are Brazil, the United States, and India (Schill, 2013). In the United Kingdom, one of the main biomass initiatives is the implementation of a combined heat power plant with a $10 \mathrm{MW}$ capacity at Heathrow Airport, helping the airport meet its goal of reducing carbon emissions by 34\% (Tagliaferri et al., 2018).

Biomass blending should focus on eliminating the constraints of biomass supply. A majority of biomass resources are seasonal, within a period of one to six months to obtain output. However, most available studies regarding biomass energy are limited to a single biomass type only (Özdenkçi et al., 2017). Kedah is well known as the rice bowl of Malaysia and the country generates an abundance of rice paddy residue (roughly 7 million tons) (Shafie, 2015).

${ }^{*}$ Corresponding author's email: shafini@uum.edu.my, Tel. +604-928-7038, Fax. +604-928-7070

Permalink/DOI: https://doi.org/10.14716/ijtech.v9i8.2752 
The utilization of garden waste for electricity generation could provide purpose for the unused wood waste in this region, most of which is currently sent to landfills. Only $2 \%$ of this waste is used as fertilizer (Zakareta \& Shafie, 2016). Maize and coconut waste also have the potential to be used as boiler fuel. While there are many studies regarding biomass energy (Abdul Malek et al., 2017), knowledge about the environmental impact of the whole electricity generation life cycle is still very limited. This study analyses the life cycle assessment (LCA) of biomass blending in electricity production with a focus on the state of Kedah. The LCA of the environmental and life cycle costs (LCC) inherent in blending potential biomass resources towards electricity generation in the northern region will be investigated.

\section{METHODS}

Kedah is located in the northwestern part of Peninsular Malaysia. Kedah produces 34 types of crops, including industrial and cash crops, but only four crops have been chosen for blending in the biomass power plant: rice paddy, coconut, maize, and sugarcane (Shafie et al., 2018). Figure 1 shows the block diagram concept applied in this study. Table 1 lists the biomass feedstock production in the northern region, which includes the crop residues used for blending. Table 1. Agriculture crops and their residue productions in Kedah, 2015 (Department of Agriculture, 2016a; Department of Agriculture, 2016b).

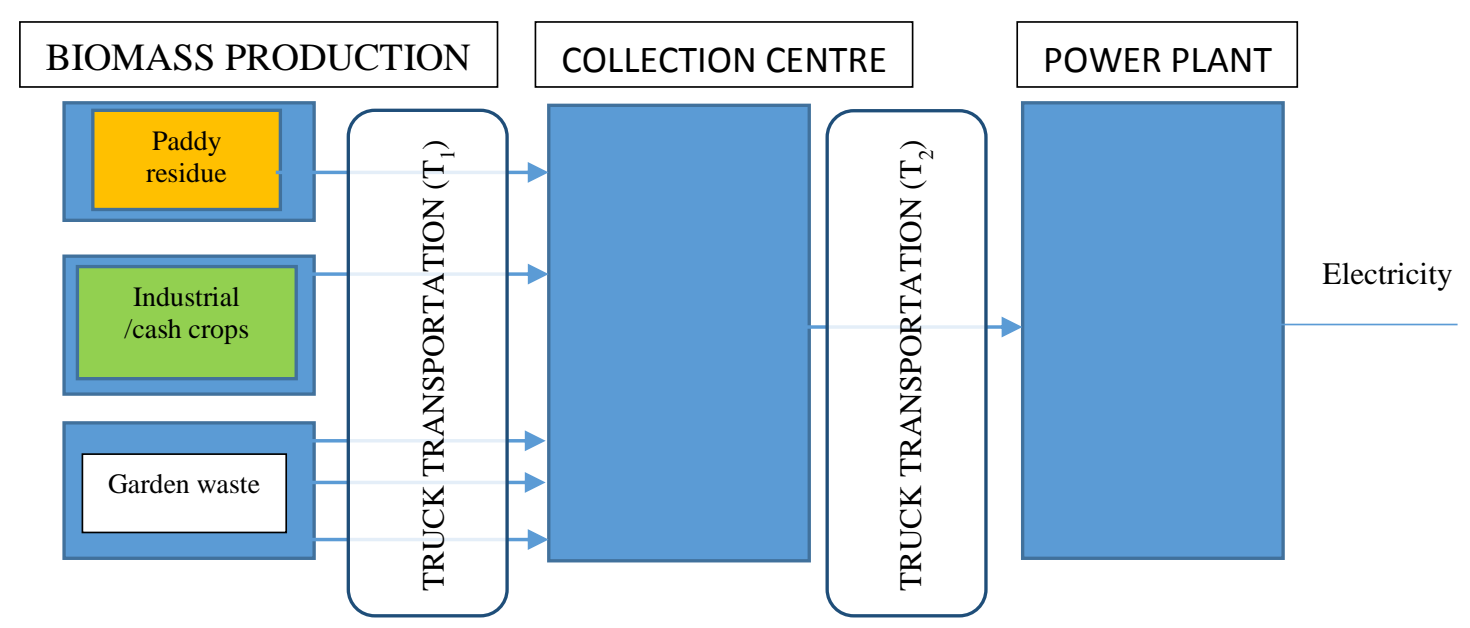

Figure 1 Block diagram concept applied in this study

Table 1 Agriculture crops and their residue productions in Kedah, 2015

\begin{tabular}{llc}
\hline Agriculture Crop & \multicolumn{1}{c}{ Residue } & Production (MTon) \\
\hline Paddy & Rice straw & $777,135.0$ \\
& Rice husk & $227,959.6$ \\
Industrial crops & Coconut & $6,745.0$ \\
Cash crops & Maize stalk & $3,008.7$ \\
& Sugarcane & 969.3 \\
Garden waste & Total garden waste & $38,460.4$ \\
\hline
\end{tabular}

\subsection{Life Cycle Assessment (LCA) Approach}

The system boundary applied for this study is shown in Figure 2. The goal of this study is to generate one $\mathrm{kWh}$ of electricity using a process involving biomass production $(\mathrm{P})$, transportation $\left(\mathrm{T}_{1}\right)$, a collection center $(\mathrm{CC})$, transportation $\left(\mathrm{T}_{2}\right)$, and power generation $(\mathrm{E})$. Figure 2 shows the block diagram concept used for whole study. From this, the life cycle of environmental and 
economic impacts will be analyzed, starting with crop production and following through to electricity generation, as set in the system boundary. All the crops listed in Table 1 will be

\section{POWER GENERATION}

Process plan: Energy (net calorific value) [kWh]

The names of the basic processes are shown.

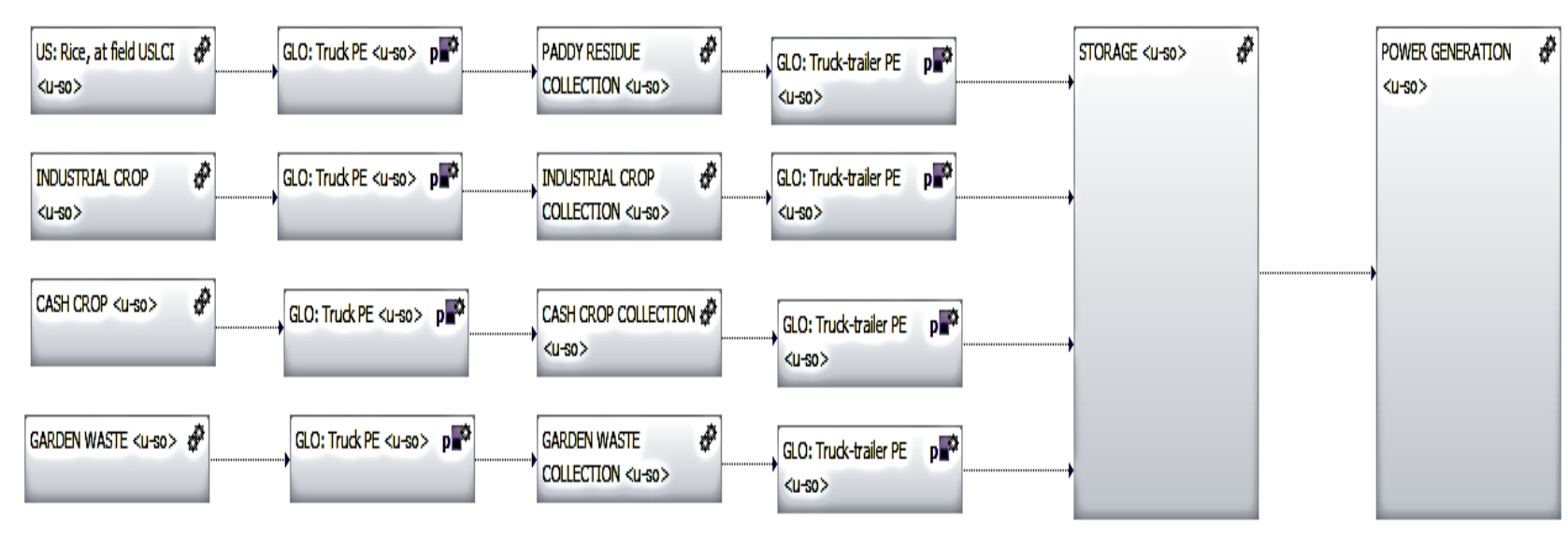

consumed as feedstock by the power plant.

Figure 2 The system boundary applied in this study

Table 2 shows the overall data consumed in both the LCA and life cycle cost (LCC) analyses. Surveys and interviews were applied to obtain the data for this study.

Table 2 The data resources for each process

\begin{tabular}{ll}
\hline \multicolumn{1}{c}{ Process } & \multicolumn{1}{c}{ Data Resources } \\
\hline Crop production & Muda Agriculture Development Authority (MADA), Department of \\
& Agriculture (DOA), Department of Environment (DOE), Selected farmers \\
Crop collection & MADA, E-idaman, SWCorp, Kedah district council \\
Collection center & MADA \\
Transportation & Bernas lorry driver, MADA lorry driver, E-Idaman lorry driver \\
Power plant & Rice mills \\
\hline
\end{tabular}

\subsection{Environmental Assessment}

The LCA was applied to create a base case, estimating the environmental impact of the process with a goal of one $\mathrm{kWh}$ of electricity generation at the power plant from each biomass resource. The system boundary consists of all the processes in Figure 2. The equations involved in the environmental analysis were taken from previous studies (Shafie et al., 2014) related to Equations 7 through 12. The life cycle inventory of the LCA methodology is the collection of data, which comprises the data assembly for the inputs and outputs of the product system. Some data was obtained through literature sources, and that data was assumed to be similar to the data for the technology selected in this study. A paper by (Sultana \& Kumar, 2011) indicated that there is an unintended that not all the data necessary for a LCA study was delivered from a single industry, but regular norms essential to the preparation of such a study support the evaluation of environmental effects. That being said, data was cited from some international databases, such as the Australia Database, the United States Inventory Database, and the SimaPro LCA software program. 


\subsection{Crop Production}

The crop production data considered paddy, corn, and coconut plantations. The crop plantation emissions consisted of chemical, fertilizer, and fuel consumption, as well as agriculture machines, water, and labor. Paddy production was the main process for obtaining rice straw and rice husks and all data regarding this production was obtained from MADA (Lembaga Kemajuan Pertanian Muda, 2017) and the DOA (Department of Agriculture, 2016b). Other crop production information, such as that on corn and coconut plantations, was obtained through Jabatan Pertanian Kedah, as well as reports. Interviews were also conducted with selected farmers for each crop.

\subsection{Transportation}

Transportation involved two paths: (1) transportation from the crop production to the collection center, $T_{R S 1}$; and (2) transportation from the collection center to the biomass power plant, $T_{R S 2}$. The distance for each path is assumed given that the power plant and collection center locations are at the center of a circular catchment area (Delivand et al., 2011). The distances were determined using Equations 3 and 4 from the study by (Shafie et al., 2014). The data on transportation emissions were drawn from the study by (Abdul Malek et al., 2017), which calculated the fuel consumption, load capacity, and distance travelled based on the following equation:

$$
E_{T}=\left(M_{F} \times D \times E F_{T}\right) / T T_{1}
$$

where $E_{T}$ is the carbon dioxide emission $\left(t \mathrm{CO}_{2} / y\right), M_{F}$ is the annual fuel requirement $(t / y), D$ is the hauling distance in kilometres, $E F_{T}$ is the emission factor of carbon dioxide $\left(\mathrm{CO}_{2}\right)$ for diesel consumption $\left(t \mathrm{CO}_{2} / \mathrm{km}\right)$, and $\mathrm{TT}_{l}$ is the truckload per trip $(t)$. The generalized cost is then calculated based on the physical form and quality of biomass, either in bale form (rice straw) or bulk form (other biomass crops) in Equation 2. The capacity for bale form is two bales of rice straw per lorry, while the capacity for bulk form is one ton per lorry.

$$
C_{T 1}=\left(\left(0.105 \times F \times D_{T 1}\right)+\left(C P_{T 1}\right)\right)
$$

The transportation cost of transporting biomass resources to the power plant $\left(C_{T 2}\right)$ is derived from Equation 3. A lorry weighing 3.5 tons and measuring $12.192 \mathrm{~m}$ was used to transport all biomass resources to the power plant. The bale capacity per truck was 36 bales. The cost involved in transportation considers the data obtained from interviews with Bernas lorry drivers, E-Idaman lorry drivers, and selected individual lorry drivers from Jabatan Pertanian Kedah, as well as the literature review. The main variables of fuel consumption, lorry driver's salary, and commission were all obtained from the interview sessions.

$$
C_{T 2}=\left(\left(0.27 \times F \times D_{T 2}\right)+\left(C D \times D_{T 2}\right) / L_{T 2}\right)
$$

\subsection{Collection Center}

The collection center existed to sustain a preferred quality level of crop residue. Some studies have been published regarding on-site collection centers (Huisman et al., 1997; Leboreiro \& Hilaly, 2011), while several authors have considered intermediate collection centers between the paddy fields and the power plant (Cundiff \& Marrsh, 1996; Tatsiopoulos \& Tolis, 2003; Delivand et al., 2011; Singh et al., 2011; Sultana \& Kumar, 2011). For this study, each biomass crop will have its own collection center with storage. The assumption is that the crop cultivating area exists as a whole with only one collection center processing biomass resources. Since the crop collection area of the power plant is circular, the cost of biomass collection can therefore be calculated as a function of the radius (Sun et al., 2013). The cost of collection center is the total of the storage site and the consideration of the cost of dry matter loss through storage (Turhallow et al., 2009) is calculated using Equation 5. The bales are assumed to be kept in open storage, since round bales can stand with exposure to rain and other weather conditions (Gold \& Seuring, 2011). 


$$
C_{A, C C}=P P \times\left(i /\left(1-(1+i)^{-}\right.\right.
$$

where $C_{A, C C}$ the annual capital cost (RM), $P P$ is the purchase price (RM), $i$ is the interest rate, $n$ is the life of investment year, and $D M L$ is the dry matter loss in the collection center in ton.

$$
C_{C C}=\left(C_{A, C C} / W_{C C}\right) \times(1 / 1-D M L)
$$

\subsection{Power Plant}

In this analysis, the Kuala Muda district is deemed the suitable location for the proposed building of a power plant based on the highest availability of resources. Equation 6 is applied to calculate the output power of electricity at the power plant. The high heating values (HHV) in Equation 6 are for rice straw $(16.28 \mathrm{MJ} / \mathrm{kg})$, rice husks $(15.8 \mathrm{MJ} / \mathrm{kg})$, coconut shells $(19.27 \mathrm{MJ} / \mathrm{kg})$, coconut husks $(17.98 \mathrm{MJ} / \mathrm{kg})$, corn residue $(17.3 \mathrm{MJ} / \mathrm{kg})$, and sugarcane bagasse $(18.4 \mathrm{MJ} / \mathrm{kg}$ ) (Tye et al., 2011).

$$
E_{G E N}=H H V_{G W} \times T_{G W} / N P H R
$$

The $\mathrm{CO}_{2}$ emissions at the biomass power plant are $0.32 \mathrm{~kg}$ per $\mathrm{kWh}$, as determined by Equation 7 (Wang et al., 2015). Since Malaysia does not have the data available for solely biomass power plant generation, the emission factor for all crops fired was implicit as dry wood combustion in the boiler, which was in use from the USEPA (United States Environmental Protection Agency)(EPA, 2000) External Combustion Report (Kongnum \& Ratanawilai, 2014).

$$
E_{\text {POWER }, \mathrm{CO} 2}=P_{C} \times B F_{C} \times M W_{C O 2} / M W_{C} / H H V_{\text {crops }}
$$

The economic analysis of a biomass power plant structure can be difficult because many conversion technologies are still only at pilot scale (Evans et al., 2010). As such, the total plant capital cost for circulating bed combustors and boilers is determined using Equation 8, using a formula derived from a previous study (Shafie, 2015).

$$
C C_{P G}=5060(P P C)^{-0.073}
$$

\section{RESULTS AND DISCUSSION}

Figure 3 shows the total GHG emissions and total costs involved for each process in electricity generation in the northern region. Each figure shows the result obtained by using the system boundary setting in Figure 2. The results indicate that the most prominent GHG emissions came from transportation, with the highest contributions from rice straw, rice husks, and garden waste. Meanwhile, the top three processes affecting costs were the plantation process, the power plant process, and the collection center process.

The two resources that had significant GHG emissions in this study were rice straw and garden waste. Most of the emissions from rice straw (80\%) were from truck transportation, $T_{2}$. According to (Paredes-Sánchez et al., 2016), a biomass logistic center should be located close to promising technical, economical, and terrestrial features, and its biomass resources should be located within a $50 \mathrm{~km}$ range. Figure 4 shows the environmental impact of biomass-based electricity generation in the northern region of Malaysia. Rice straw is the main contributor of each environment variable. To address the currently popular environmental impact of climate change, rice straw and garden waste were found to contribute the most to this impact. In addition, garden waste was found to be the main contributor from the power plant process. 


\section{Crop Production}

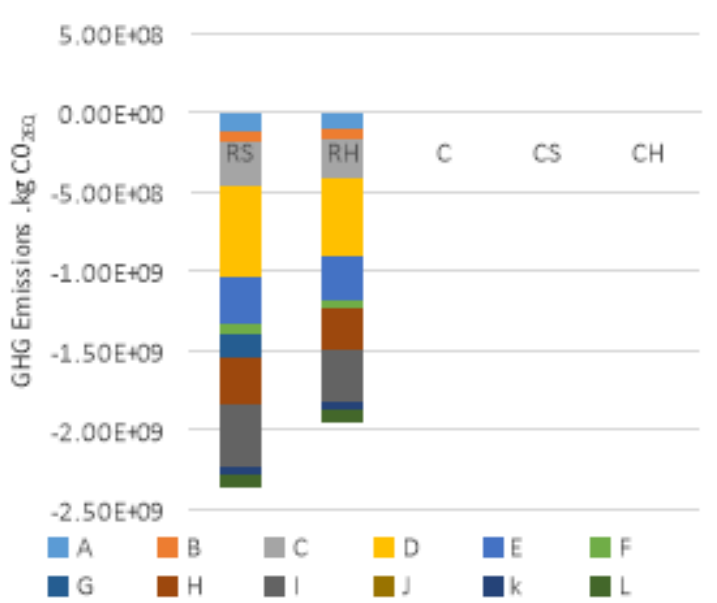

(a)

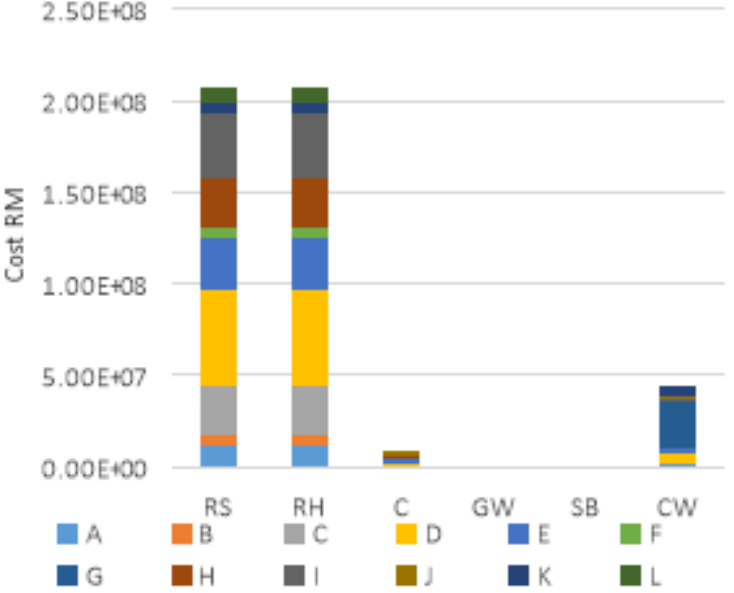

(b)

Lorry Transportation $\left(T_{l}\right)$

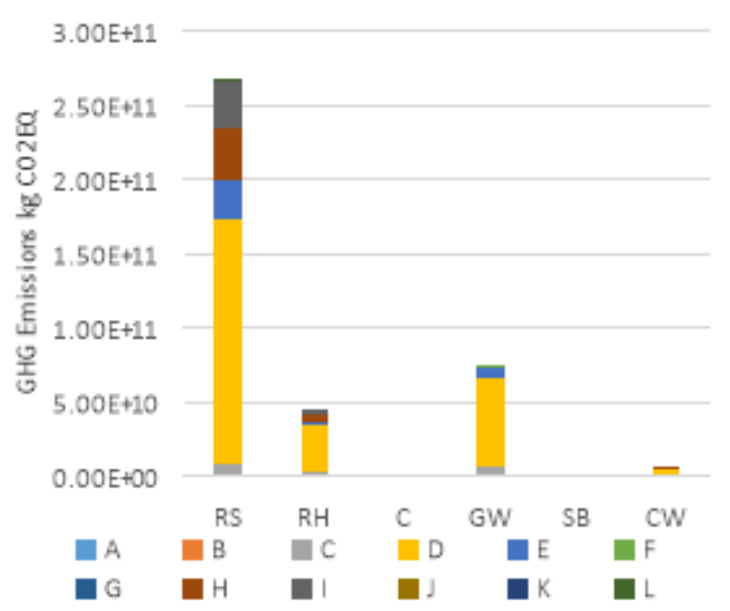

(c)

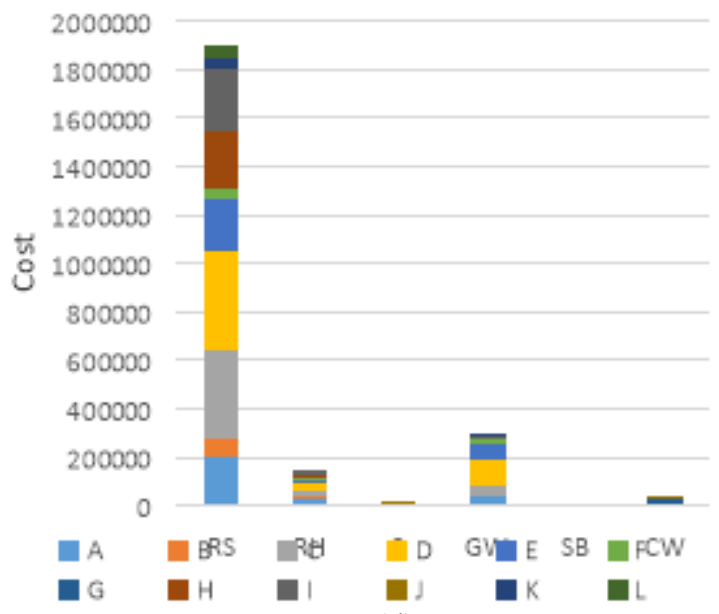

(d)

Crop Collection

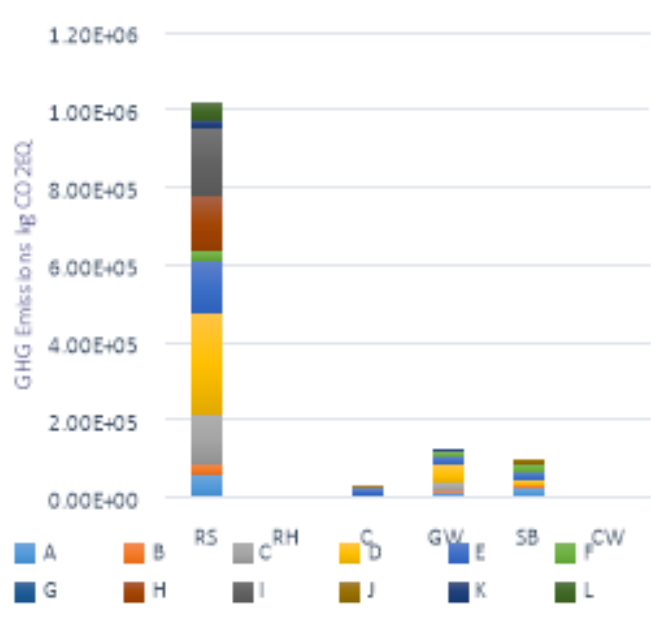

(e)

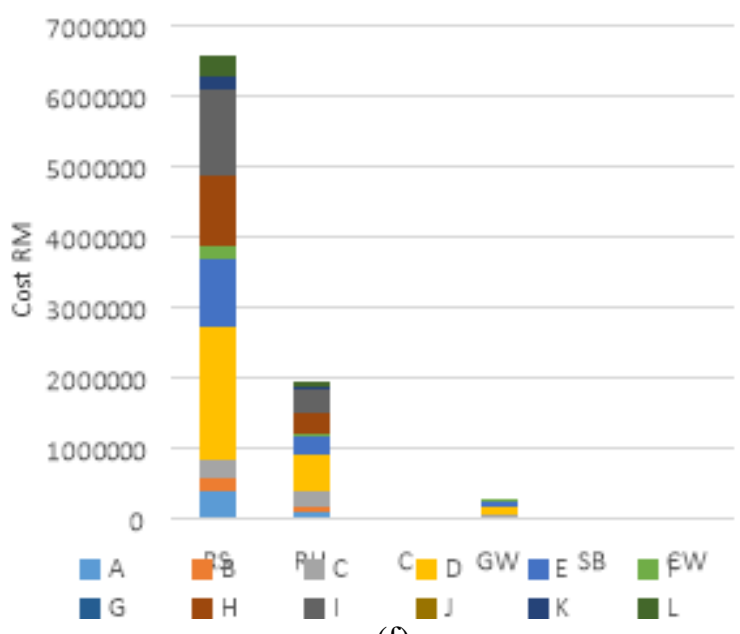

(f) 
Collection Centre

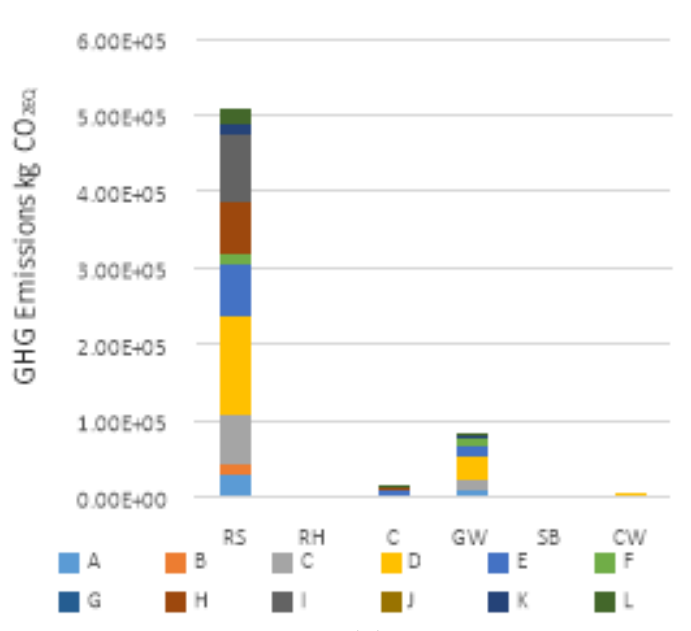

(g)

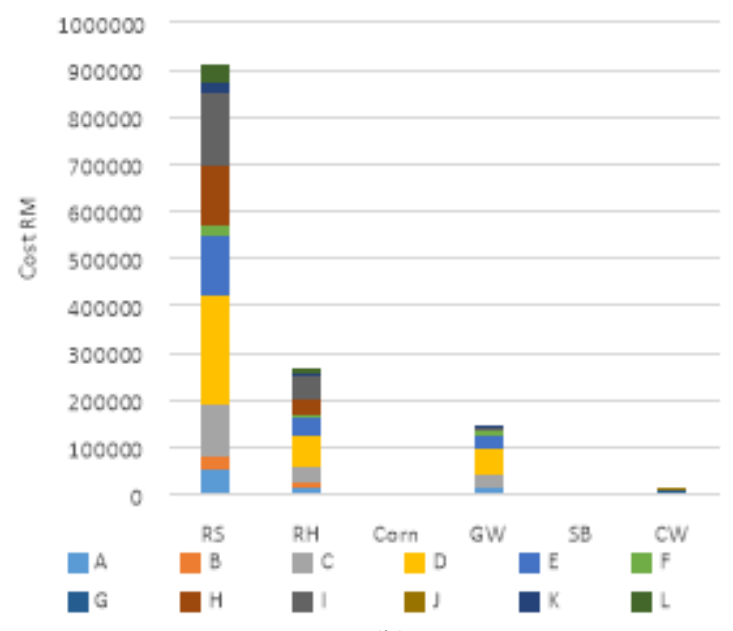

(h)

Truck Transportation $\left(T_{2}\right)$

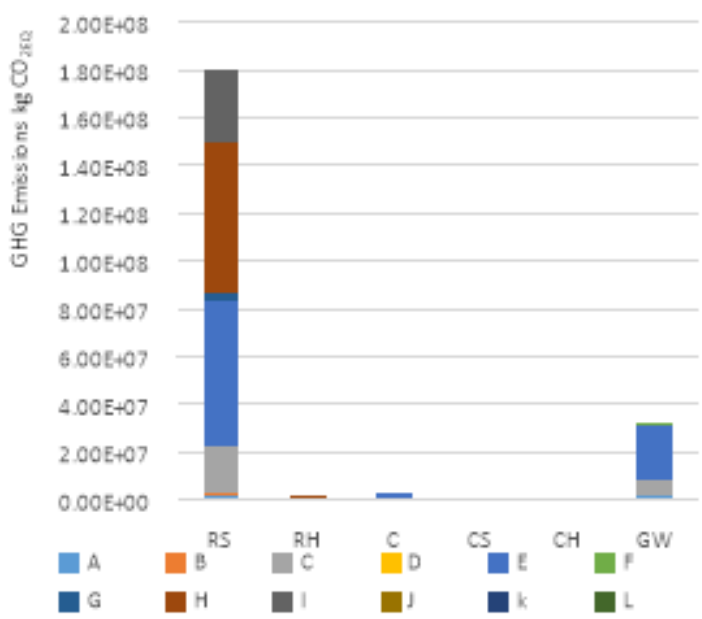

(i)

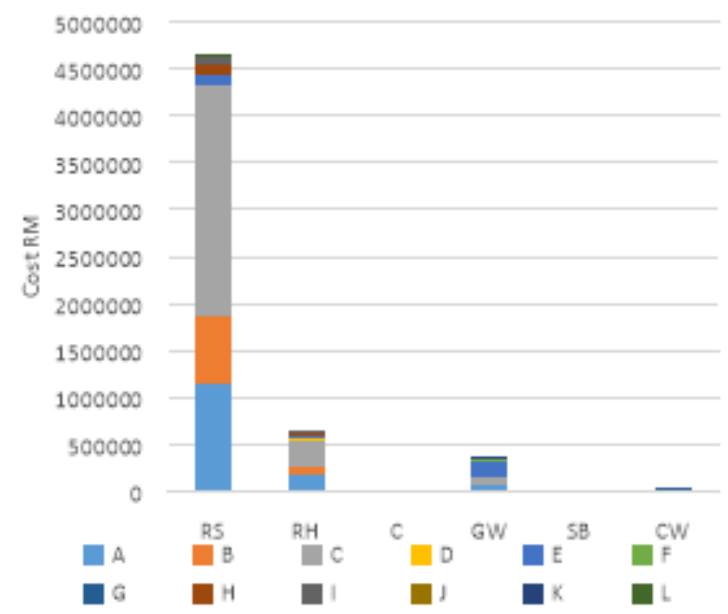

(j)

Power Plant

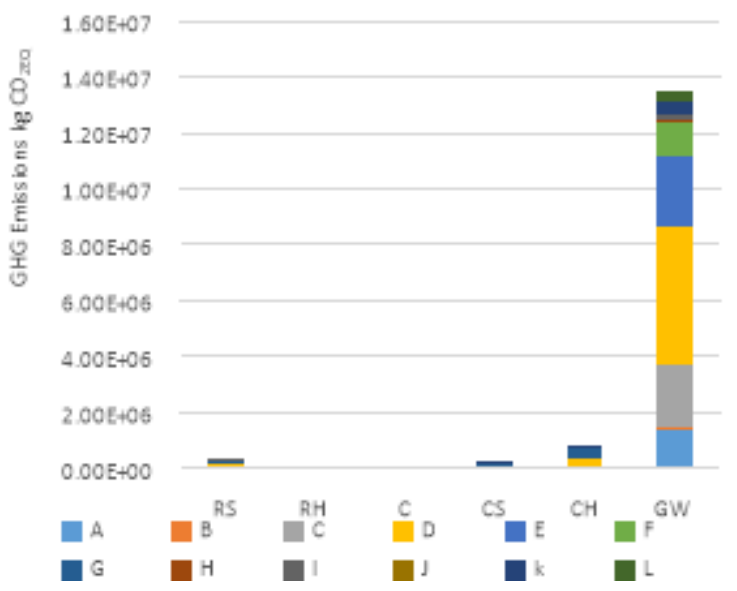

(k)

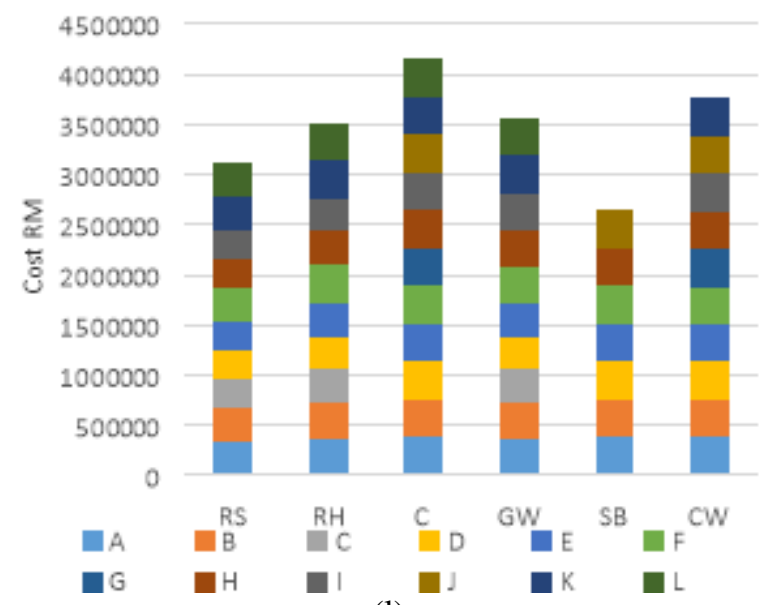

(1)

Figure 3 Total GHG emissions and costs involved for each process in electricity generation: (a) and (b) crop production; (c) and (d) lorry transportation $T_{l}$; (e) and (f) crop collection; (g) and (h) collection center; (i) and (j) truck transportation $T_{2}$; (k) and (l) power plant 


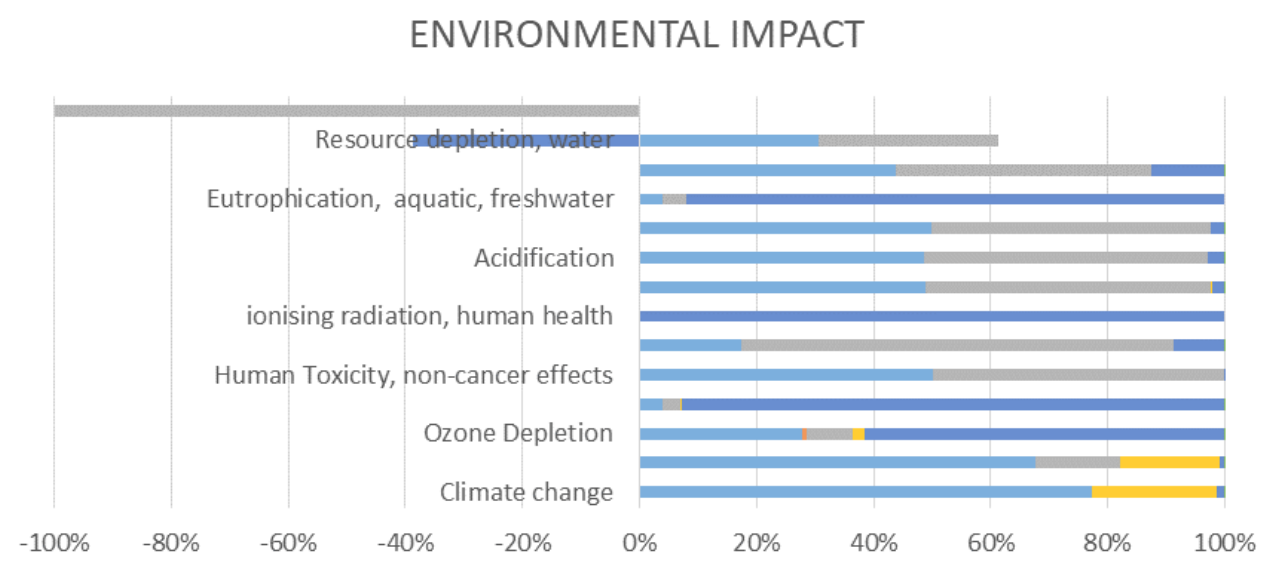

$\square$ RICE STRAW $\square$ CORN $\square$ RICE HUSK $\square$ GARDEN WASTE $\square$ COCONUT WASTE $\square$ SUGARCANE BAGASSE

Figure 4 The environmental impact of biomass-based electricity generation

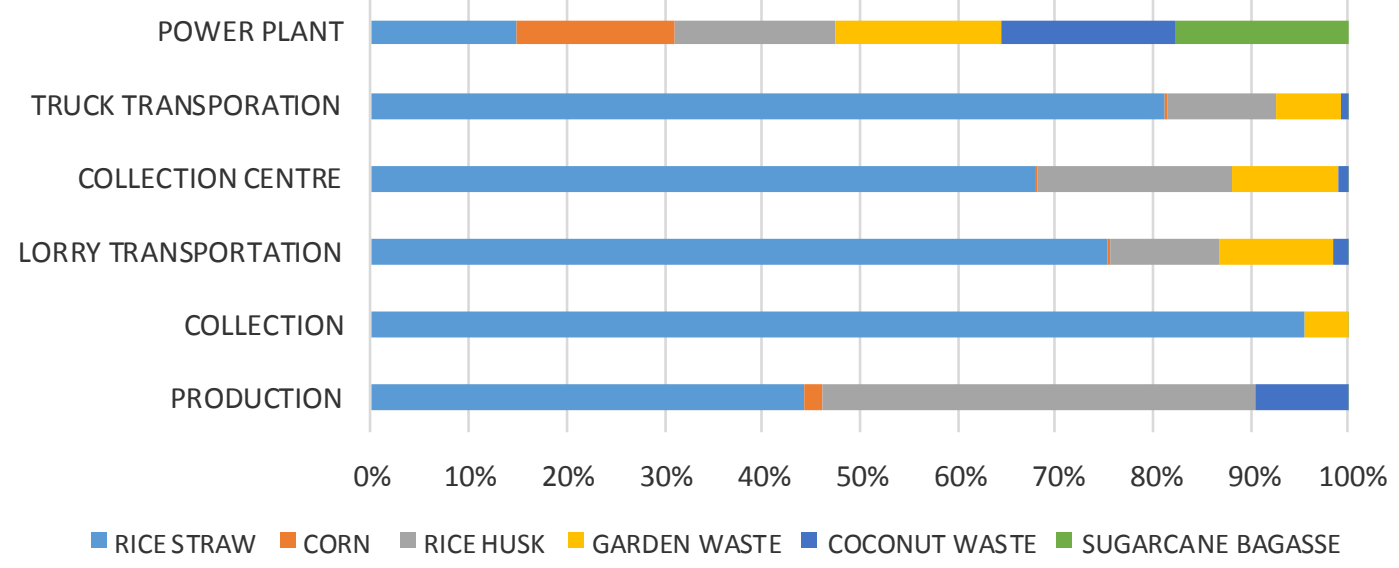

Figure 5 The life cycle cost of biomass-based electricity generation

Figure 5 shows the life cycle cost of biomass-based electricity generation. According to (ParedesSánchez et al., 2016), 70\% of all costs originated with fuel, while the transportation cost contributed roughly $12.8-22.3 \%$ of the total cost. This study found that the transportation cost contributed roughly $21.9 \%$ of the total cost. The costs for petrol, plant, and transportation of each individual residue at the power plant were divided by the electricity generated from each respective biomass resource to determine the cost of the supply (Zhang et al., 2014). The average power generating cost is between 35 and 60 USD per MWh, according to (Stich et al., 2017), and electricity generation costs differ within a wide range from less than $40 \mathrm{USD} / \mathrm{MWh}$ to greater than 200 USD/MWh. The simulation outcome of a study in Egypt indicated that the cost of the proposed rice straw power plant ranges between 10.55 and $6.33 \phi / \mathrm{kWh}$ (Abdelhady et al., 2018).

Table 3 The life cycle emissions and costs for each available biomass resource

\begin{tabular}{|c|c|c|c|c|c|c|c|}
\hline $\begin{array}{l}\text { Biomass } \\
\text { resources }\end{array}$ & $\begin{array}{l}\text { Rice } \\
\text { straw }\end{array}$ & $\begin{array}{l}\text { Corn } \\
\text { residue }\end{array}$ & $\begin{array}{l}\text { Rice } \\
\text { husks }\end{array}$ & $\begin{array}{c}\text { Sugarcane } \\
\text { tops }\end{array}$ & $\begin{array}{l}\text { Garden } \\
\text { waste }\end{array}$ & $\begin{array}{c}\text { Sugarcane } \\
\text { bagasse }\end{array}$ & $\begin{array}{l}\text { Coconut } \\
\text { residue }\end{array}$ \\
\hline $\begin{array}{l}\text { Emissions } \\
(\mathrm{kg} / \mathrm{kWh})\end{array}$ & $6,400.04$ & 7.34 & $3,207.22$ & 0.02 & $1,468.88$ & 1.91 & $1,082.35$ \\
\hline $\begin{array}{l}\text { Costs } \\
(\mathrm{RM} / \mathrm{kWh})\end{array}$ & 5.37 & 0.19 & 1.78 & 16.10 & 0.01 & 1.33 & 1.25 \\
\hline
\end{tabular}


The life cycle for GHG emissions is higher due to the transportation process. Local criteria (such as power plant positioning, crop management, and fertilization practices) also require additional assessment to reduce environmental impact. Other studies showed life cycle emissions from 1,000-5,000 g/kWh for different types of biomass resources (Kadiyala et al, 2016).

\section{CONCLUSION}

This paper determined the GHG emissions created by electricity generation, based on different crop bases. The results ranged from $0.02 \mathrm{~kg} \mathrm{CO} 2 \mathrm{EQ} / \mathrm{kWh}$ to $6,400.04 \mathrm{~kg} \mathrm{CO} 2 \mathrm{EQ} / \mathrm{kWh}$. Meanwhile, the costs varied from RM0.01 $/ \mathrm{kWh}$ to RM16.10/kWh. The transportation process requires extra extension due to its high GHG emissions and high consumption costs. This paper can offer help as a guideline and provide information for decision maker to create future policies in biomass energy.

\section{ACKNOWLEDGEMENT}

This research was financially supported by the Ministry of Higher Education Malaysia (FRGS13260/2015). The authors would like to thank the reviewers and associate editor for their comments that have improved this manuscript.

\section{REFERENCES}

Abdelhady, S., Borello, D., Shaban, A., 2018. Techno-economic Assessment of Biomass Power Plant Fed with Rice Straw: Sensitivity and Parametric Analysis of the Performance and the LCOE. Renewable Energy, Volume 115, pp. 1026-1034

Abdul Malek, A.B.M., Hasanuzzaman, M., Abd Rahim, N., Al Turki, Y., 2017. Technoeconomic Analysis and Environmental Impact Assessment of a 10 MW Biomass-based Power Plant in Malaysia. Journal of Cleaner Production, Volume 141, pp. 502-513

Cundiff, J.S., Marrsh, L.S., 1996. Harvest and Storage Costs for Bales of Switchgrass in the Southeastern United States. Bioresource Technology, Volume 56(1), pp. 95-101

Delivand, M.K., Barz, M., Gheewala, S.H., 2011. Logistics Cost Analysis of Rice Straw for Biomass Power Generation in Thailand. Energy, Volume 36(3), pp. 1435-1441

Department of Agriculture, 2016a. Industrial Crops Statistics. Putrajaya: Department of Agriculture

Department of Agriculture, 2016b. Paddy Statistics of Malaysia. Kuala Lumpur: Department of Agriculture, Peninsular Malaysia

EPA, 2000. Chapter 3: Stationary Internal Combustion Sources AP 42, Fifth Edition, Volume I. United State: United States Environmental Protection Agency

Evans, A., Strezov, V., Evans, T.J., 2010. Sustainability Considerations for Electricity Generation from Biomass. Renewable and Sustainable Energy Reviews, Volume 14(5), pp. 14191427

Gold, S., Seuring, S., 2011. Supply Chain and Logistics Issues of Bio-energy Production. Journal of Cleaner Production, Volume 19(1), pp. 32-42

Hossain, N., Zaini, J.H., Mahlia, T.M.I., 2017. A Review of Bioethanol Production from Plantbased Waste Biomass by Yeast Fermentation. International Journal of Technology, Volume 8(1), 5-18

Huisman, W., Venturi, P., Molenaar, J., 1997. Costs of Supply Chains of Miscanthus giganteus. Industrial Crops and Products, Volume 6(3-4), pp. 353-366

Kadiyala, A., Kommalapati, R., Huque, Z., 2016. Evaluation of the Life Cycle Greenhouse Gas Emissions from Different Biomass Feedstock Electricity Generation Systems. Sustainability, Volume 8(11), pp. 1-12 
Kongnum, P., Ratanawilai, S., 2014. Catalytic Pyrolysis of Coconut Shell for Bio-oil. Int'l Journal of Advances in Chemical Engg., \& Biological Sciences, Volume 1(1), pp. 63-66

Leboreiro, J., Hilaly, A.K., 2011. Biomass Transporation Model and Optimum Plant Size for the Production of Ethanol. Bioresource Technology, Volume 102(3), pp. 2712-2723

Lembaga Kemajuan Pertanian Muda, 2017. Purata Hasil Padi (Average Rice Product). Available Online at http://www.mada.gov.my/, Accessed on 1 January 2017

Özdenkçi, K., Blasio, C.D., Muddassar, H.R., Melin, K., Oinas, P., Koskinen, J., Sarwar, G., Järvinen, M., 2017. A Novel Biorefinery Integration Concept for Lignocellulosic Biomass. Energy Conversion and Management, Volume 149, pp. 974-987

Paredes-Sánchez, J.P., García-Elcoro, V.E., Rosillo-Calle, F., Xiberta-Bernat, J., 2016. Assessment of Forest Bioenergy Potential in a Coal-producing Area in Asturias (Spain) and Recommendations for Setting up a Biomass Logistic Centre (BLC). Applied Energy, Volume 171, pp. 133-141

Schill, S.R., 2013. IEA Task40: Biomass Provides 10 Percent of Global Energy Use. Biomass Magazine

Shafie, S.M., 2015. An Integrated Approach for Techno-economic and Environmental Analysis of Power Generation from Paddy Residue in Malaysia. PhD Dissertation, University of Malaya, Kuala Lumpur

Shafie, S.M., Masjuki, H.H., Mahlia, T.M.I., 2014. Rice Straw Supply Chain for Electricity Generation in Malaysia: Economical and Environmental Assessment. Applied Energy, Volume 135, pp. 299-308

Shafie, S.M., Othman, Z., Hami, N., 2018. A Model of Blended Paddy Residue with Other Biomass Power Plant based on Techno-economic and Environment in Malaysia. Technical Report - FRGS Grant: Universiti Utara Malaysia

Singh, J., Panesar, B.S., Sharma, S.K., 2011. Geographical Distribution of Agricultural Residues and Optimum Sites of Biomass Based Power Plant in Bathida, Punjab. Biomass and Bioenergy, Volume 35(10), pp. 4455-4460

Stich, J., Ramachandran, S., Hamacher, T., Stimming, U., 2017. Techno-economic Estimation of the Power Generation Potential from Biomass Residues in Southeast Asia. Energy, Volume 135, pp. 930-942

Sultana, A., Kumar, A., 2011. Optimal Configuration and Combnation of Multiple Lignocellulosic Biomass Feedstocks Delivery to a Bioenergy. Bioresource Technology, Volume 102(21), pp. 9947-9956

Sun, Y., Wanga, R., Liu, J., Xiao, L., Lin, Y., Kao, W., 2013. Spatial Planning Framework for Biomass Resources for Power Production at Regional Level: A Case Study for Fujian Province, China. Applied Energy, Volume 106, pp. 391-406

Tagliaferri, C., Evangelisti, S., Clift, R., Lettieri, P., 2018. Life Cycle Assessment of a Biomass CHP Plant in UK: The Heathrow Energy Centre Case. Chemical Engineering Research and Design, Volume 133, pp. 210-221

Tatsiopoulos, I.P., Tolis, A.J., 2003. Economic Aspects of the Cotton-stalk Biomass Logistics and Comparison of Supply Chain Methods. Biomass and Bioenergy, Volume 24(3), pp. 199-214

Turhallow, A., Wilkerson, E., Sokhansanj, S., 2009. Cost Methodology for Biomass Feedstocks: Herbaceous Crops and Agricultural Residues. US: Bioenergy Resource and Engineering Systems

Tye, Y.Y., Lee, K.T., Abdullah, W.N.W., Leh, C.P., 2011. Second-generation Bioethanol as a Sustainable Energy Source in Malaysia Transportation Sector: Status, Potential and Future Prospects. Renewable and Sustainable Energy Reviews, Volume 15(9), pp. 45214536 
Wang, C., Zhang, L., Chang, Y., Pang, M., 2015. Biomass Direct-fired Power Generation System in China: An Integrated Energy, GHG Emissions, and Economic Evaluation for Salix. Energy Policy, Volume 84, pp. 155-165

Zakareta, M.M., Shafie, S.M., 2016. Garden Waste Management: Process and Cost. Paper Presented at the Proceedings of Symposium on Technology Management \& Logistics, Kedah

Zhang, Q., Zhou, D., Fang, X., 2014. Analysis on the Policies of Biomass Power Generation in China. Renewable and Sustainable Energy Reviews, Volume 32, pp. 926-935 